\section{Results}

The blood urea values did not alter appreciably and are not shown. The results of the other investigations are shown in the table. After 10 days, in all but one patient in each group, the creatinine clearance fell, the average decrease being about $25^{\prime \prime} .(\mathbf{P}<0.01)$. At the same time the serum creatinine level rose by an average of about $38^{\prime \prime}$. $(\mathrm{P}<0.01)$. Most of the change in creatinine clearance occurred in the first three days; the further small decrease in creatinine clearance between day three and day 10 was not statistically significant. These results contrasted considerably with the ${ }^{i 1} \mathrm{Cr}$-edetic acid clearance figures, which showed no significant change.

\section{Discussion}

Our results indicate that salicylate treatment was associated with a sustained increase in plasma creatinine levels and a fall in creatinine clearance. Since chromium edetate clearance remained unaffected it is reasonable to assume that these changes did not result from a disturbance of glomerular function, unless salicylate induces a specific interference with filtration of creatinine in the glomerulus. More likely explanations include disturbance of creatinine binding to serum protein or competitive inhibition of tubular secretion of creatinine. The further possibility of abnormal production of creatinine is unlikely as analysis of the daily output of creatinine showed no increase in total excretion. To ensure that the presence of salicylate in plasma had not interfered with the assay of creatinine, salicylate in a concentration of $1.5 \mathrm{mmol} / 1(20 \mathrm{mg} / 100 \mathrm{ml})$ plasma was added to eight specimens of serum. Assays of creatinine with and without salicylate showed no difference in the results.
Clearly the creatinine clearance test is not suitable for assessing renal function in patients suffering from rheumatoid arthritis since many of these will be receiving salicylate, and the results of the investigations carried out by Sørensen, ${ }^{9}$ Bulger et al, " Burry, ${ }^{11}$ Jeremy et al, ${ }^{12}$ and the New Zealand Rheumatism Assoziation study ${ }^{13}$ need to be reassessed in this context. Further studies are indicated to determine whether other drugs have an effect on creatinine clearance similar to that of salicylates and to determine the mode of action of salicylates.

When the creatinine clearance test is used to detect renal disease or monitor progress of renal disease a careful history of the patient's drug-taking habits must be obtained before the results can be assessed.

\section{References}

1 Popper, H, and Mandel, E, Ergebnisse der Inneren Medizin und Kinderheilkunde, 1937, 53, 685 .

2 Miller, B F, et al, fournal of Clinical Investigation, 1952, 31, 309

"3erlyn, G M, et al, Lancet, 1964, 2, 874.

' Beeley, L, and Kendall, M J, British Medical Fournal, 1971, 1, 707.

'Robert, M, et al, British Medical fournal, 1972, 2, 466.

"Stacey, B D, and Thorburn, G D, Science, 1966, 152, 1076.

- Garnett, E S, Parsons, V, and Veall, N, Lancet, 1967, 1, 818

" Favre, H R, and Wing, A J, British Medical fournal, 1968, 1, 84

${ }^{9}$ Sørensen, A W S, Acta Rheumatologica Scandinavica, 1960, 6, 115.

11) Bulger, R J, Healey, L A, and Polinsky, P, Annals of the Rheumatic Diseases, 1968, 27, 339.

' Burry, H C, Annals of the Rheumatic Diseases, 1972, 31, 65.

1: Jeremy, R, et al, Australian Rheumatism Association's Annual Meeting Proceedings, 1972, Abstract 15, p 12.

${ }^{13}$ New Zealand Rheumatism Association, British Medical fournal, 1974, 1, 593.

\title{
Doppler ultrasound method for detecting human fetal breathing in utero
}

\author{
E S BOYCE, G S DAWES, J D GOUGH, E R POORE
}

British Medical fournul, 1976, 2, 17-18

\section{Summary}

An audible Doppler ultrasound method for detecting human fetal breathing movements in utero has been developed. The frequencies synchronous with fetal breathing movements probably originate from the lung rather than the chest wall. This method is much cheaper and simpler than the ultrasound A-scan method and is suitable for screening large numbers of people.

\section{Introduction}

Over the past five years fetal breathing movements in utero have been investigated in sheep and in $\operatorname{man}^{1 *}$ using an ultrasound

\footnotetext{
Nuffield Institute for Medical Research, University of Oxford, Oxford OX3 9DS

E S BOYCE, MB, MRCOG, research officer

G S DAWES, DM, FRS, director

J D GOLGH, MB, MRCOG, research officer

E R POORE, BSC, research assistant
}

A-scan method, and there is evidence that the continued presence of normal fetal breathing is an index of health. ${ }^{3}$ The A-scan method, however, requires expensive and complex machines that need considerable practise to use, and it is unsuitable for screening large numbers of patients. We therefore searched for a simple method of detecting fetal breathing movements.

\section{Technique}

The maximum velocity of human fetal chest wall movements in utero is only $1-3 \mathrm{~cm} / \mathrm{s}$ as measured by A-scan ultrasound; this was confirmed using a pulsed Doppler system giving a shift frequency $<70 \mathrm{~Hz}$ with a transducer pulsed at $2 \mathrm{MHz} .{ }^{4}$ This shift frequency is rejected by the filtering in most continuous Doppler systems available clinically.

Nevertheless, audible signals of a character consistent with fetal breathing (fig 1) were obtained using a Sonicaid D205 instrument in more than 70 pregnant women. The validity of this attribution depends, firstly, on the fact that the signal was independent of maternal respiratory movement or pulse rate and of fetal heart rate. When present the signal was within the range $30-90$ per minute, was prolonged for more than one fetal heart beat, and was of a rough character-that is, not a pure tone. It was also independent of fetal movements or hiccoughs perceptible to the mother. Alternate use of A-scan and continuous Doppler ultrasound systems in 32 patients showed that the audible signal had the same features as that of fetal breathing 
movements; both appeared and disappeared together and had the same rate. In four patients the fetal breathing movement was visible on the maternal abdomen. Using the criteria described by Boddy and Mantell, ${ }^{5}$ simultaneous recording of abdominal movement with a strain-gauge transducer showed the continuous Doppler signal (processed by an appropriate zero-crossing frequency meter) to be contemporaneous (fig 1).

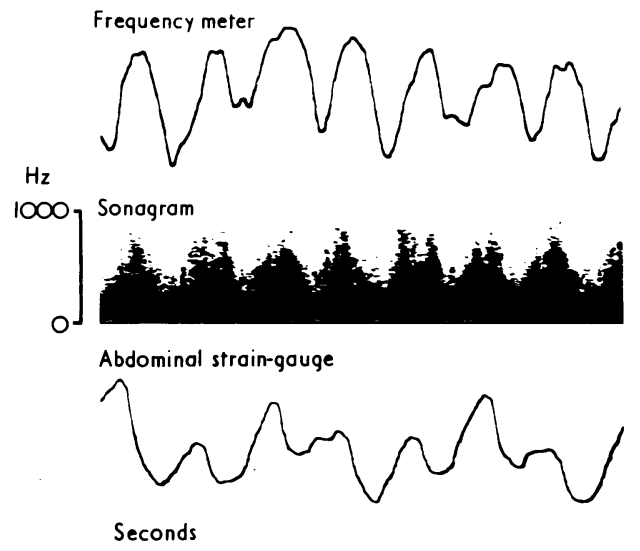

FIG 1-Records of human fetal breathing movements recorded from maternal abdomen by continuous Doppler system (zero-crossing frequency meter, and sonagram) and by strain-gauge. Strain-gauge record of abdominal wall movements shows components due to both maternal and fetal breathing; the maternal is the slower.

The audible signals recorded from a continuous Doppler system and attributed to fetal breathing probably originate from the lung itself. A signal similar in character, with multiple Doppler shift frequencies, has been recorded from fluid-filled lungs excised from fetal lambs near term and immersed in saline. When as little as $0.3 \mathrm{ml}$ of saline was pumped in and out of the trachea at $0.8 \mathrm{~Hz}$ a signal (fig 2) was obtained using a transducer coupled to the saline like that recorded from the human maternal abdomen. This fluid displacement corresponds to that recorded from a tracheal flowmeter implanted in a fetal lamb making normal breathing movements in utero. ${ }^{6}$ The earliest gestational age at which the signal has yet been observed in human pregnancy is 32 weeks. It remains to be seen whether its presence is dependent on pulmonary maturation sufficient for lung expansion; it was difficult to detect the signal from the lungs of two very premature lambs.

\section{Discussion}

The continuous Doppler ultrasound method has several advantages over the A-scan method. The machines are in common use in most obstetric hospitals, and are relatively inexpensive and simple to use. The audible signal produced by fetal breathing movements is easily identified and can be distinguished from other intra-abdominal audible ultrasound phenomena by the criteria shown in the table. Many midwives and obstetricians have heard the signals of fetal breathing but have attributed them to events associated with the maternal pulse. One further distinguishing feature is that from time to
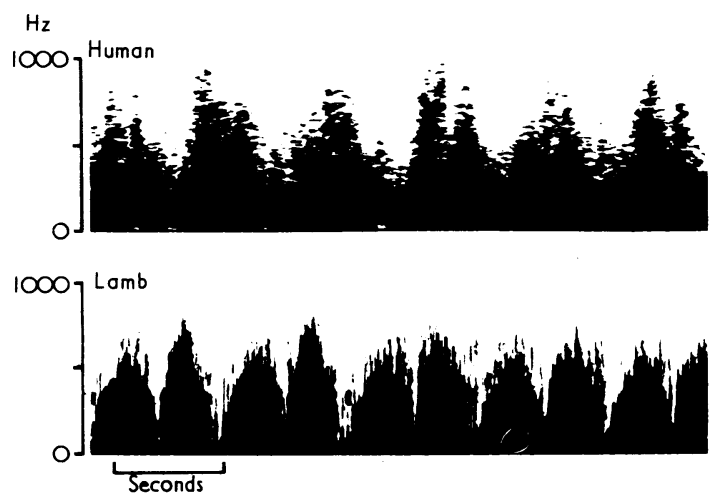

FIG 2-Sonagrams, recorded by a continuous Doppler system, of human fetal breathing from the maternal abdomen (above) and from an isolated fetal lamb's lung (gestational age 130 days) immersed in fluid and rhythmically inflated with $0.3 \mathrm{ml}$ saline at $0.8 \mathrm{~Hz}$ (below). Lamb's lung sonagram shows biphasic frequency changes with inflation and deflation. Both records show similar wide range of frequencies.

Audible Doppler shift frequencies resulting from intra-abdominal movements

\begin{tabular}{|c|c|c|c|}
\hline & Origin & Rate* & Characteristics \\
\hline \multirow[t]{4}{*}{ Fetal } & Heart & $120-160 / \mathrm{min}$ & Rate, high-frequency sound \\
\hline & $\begin{array}{l}\text { Umbilical cord } \\
\text { Movement }\end{array}$ & $\begin{array}{l}120-160 / \mathrm{min} \\
\text { Isolated }\end{array}$ & $\begin{array}{l}\text { Irom valve movement } \\
\text { Rate } \\
\text { Abrupt, large-amplitude }\end{array}$ \\
\hline & Hiccoughs & $5-20 / \mathrm{min}$ & $\begin{array}{l}\text { signals } \\
\text { Abrupt, large-amplitude }\end{array}$ \\
\hline & Breathing & $30-90 / \mathrm{min}$ & $\begin{array}{l}\text { Rate, rushing noises with } \\
\text { smooth rise and fall }\end{array}$ \\
\hline Placental & $\begin{array}{l}\text { Souffle: } \\
\text { fetal } \\
\text { maternal }\end{array}$ & $\begin{array}{l}120-160 / \mathrm{min} \\
70-90 / \mathrm{min}\end{array}$ & $\begin{array}{l}\text { Rate } \\
\text { Rate }\end{array}$ \\
\hline \multirow[t]{3}{*}{ Maternal } & Aortic flow & $70-90 / \mathrm{min}$ & Rate, synchronous with \\
\hline & Uterine artery flow & $70-90 / \mathrm{min}$ & Rate, synchronous with \\
\hline & Breathing & $15-25 / \mathrm{min}$ & $\begin{array}{l}\text { radial pulse } \\
\text { Rate }\end{array}$ \\
\hline
\end{tabular}

*To be distinguished from the Doppler shift frequencies.

time the former ceases; the latter does not. The method provides a simple screening procedure that can be used in the antenatal clinic or ward.

This work was carried out with the aid of grants from the Medical Research Council. We thank Professor A C Turnbull for his help; the consulting staff of the John Radcliffe Hospital for access to patients under their care; the ultrasonics unit of the department of medical physics at Bristol for technical advice and equipment; and the nursing staff and the subjects who volunteered for the study.

\section{References}

${ }^{1}$ Boddy, K, and Robinson, J S, Lancet, 1971, 2, 1231.

2 Dawes, G S, New England fournal of Medicine, 1974, 290, 557.

${ }^{3}$ Boddy, K, and Dawes, G S, British Medical Bulletin, 1975, 31, No 1, 3.

4 Gough, J D, and Poore, E R, unpublished.

5 Boddy, K, and Mantell, C D, Lancet, 1972, 2, 1219.

${ }^{6}$ Dawes, G S, et al, fournal of Physiology, 1972, 220, 119. 